\title{
Dinamika Kebijakan Pembelajaran Daring di Era Pandemi Covid-19
}

\author{
Yenik Pujowati ${ }^{*}$ \\ Fakultas IImu Sosial dan IImu Politik Universitas Wijaya Kusuma \\ JI. Dukuh Kupang XXV No.54 Dukuhpakis Kota Surabaya 60225 Jawa Timur \\ Email : yenikpujo@uwks.ac.id
}

Naskah diterima 13 September 2021, Revisi 2 Oktober 2021, Terbit 29 Oktober 2021

DOI: doi.org/10.21107/pamator.v14i2.11574

\begin{abstract}
The purpose of the research is to find out how the dynamics of online learning policies are in the Covid-19 pandemic era. The increasingly widespread spread of the Covid-19 pandemic has become one of the inhibiting factors in the world of education. The government's policy is to implement the Work from Home work pattern, namely all teaching and learning activities must be carried out at home, online learning to prevent the spread of Covid-19. The research method is a qualitative research, this research uses the library method, namely tracing documents, reports such as; books, journals, proceedings, articles, activity reports, news media and other written sources. Online learning activities can not be separated from problems such as; limited facilities, cultural changes, family support, not all students have laptops, cellphones. Applications that are often used in online learning such as; zoom, google classroom, teacher room and whatssap group. The researchers' conclusion; The dynamics of online learning policies in the Covid-19 pandemic era can be carried out well, according to creativity, lecturers, teachers in providing material and practice questions. The weakness of online learning such as internet network factors are uneven, not all proficient use of technology applications, lack of cultural understanding of digital media communication, cost limitations (quota internet).
\end{abstract}

Keywords: online learning, pandemic, Covid 19, digital media

\section{PENDAHULUAN}

Pembelajaran yang dilakukan melalui interaksi guru dengan siswa dalam ruangan pembelajaran di kelas. Pembelajaran ini salah satu pendampingan yang dilakukan oleh pendidik untuk mentransmisikan ilmu kepada peserta didiknya atau siswa. Oleh sebab itu, secara sederhana pembelajaran dapat dimaknai sebagai suatu proses pencerahan, pengarahan, memotivasi yang dilakukan oleh pendidik untuk membantu siswa atau mahasiswa yang mendapatkan pembelajaran mampu memahami bahan konsep pembelajaran daring yang diberikan. (Mansyur, 2020).

Dinamika kebijakan pendidikan dimasa pandemi Covid-19 adalah mengutamakan kesehatan serta keselamatan peserta didik dan pendidiknya, tenaga kependidikan, keluarga, maupun masyarakat secara umum, dengan mempertimbangkan seluruh tumbuh kembang peserta didik, baik secara kondisi psikososialnya dalam upaya pemenuhan pelayanan pendidikan. Di era pandemi Covid-19 telah memberikan dampak bersar terjadinya peningkatan kasus yang cukup tinggi, maka pemerintah berusaha untuk menangani pencegahan penyebaran virus dengan skala besar yaitu mengeluarkan peraturan untuk melakukan segala kegiatan di rumah atau disebut sebagai work from home (WFH) (Lempang et al.,2021). Mendikbud menjelaskan dalam rapat koordinasi (rakor) bersama Kepala Daerah seluruh Indonesia terkait Kebijakan Pembelajaran dimasa dampak pandemi Covid-19, dilakukan secara daring. (gtk.kemdikbud: 2020). Pemerintah telah mengeluarkan berbagai kebijakan seperti revisi surat keputusan bersama (SKB) Empat Menteri yang telah di terbitkan tanggal 7 Agustus 2020, untuk menyesuaikan kebijakan pembelajaran di era pandemi Covid-19 saat ini. Salah satu yang dimaksud agar proses pembelajaran tetap berlangsung di tengah dampak pandemi Covid-19. Salah satu model pembelajaran yang adaptif dengan situasi 
pandemi saat ini adalah pembelajaran secara daring dilaksanakan tatap muka secara langsung antara dosen atau guru dan siswa, guru harus memastikan kegiatan belajar mengajar tetap berjalan, meskipun siswa berada di rumah. Pembelajaran daring merupakan salah satu model pembelajaran yang dilaksanakan dengan menggunakan perangkat teknologi ditengah pandemi Covid-19 saat ini. Di era Pandemi Covid-19 menggunakan model proses pembelajaran daring yang sangat ditentukan oleh sistem jaringan telekomunikasi sebagai perangkat penujang yang paling utama. (Abd. Rahim Mansyur: 2020). Perubahan metode pembelajaran dengan cara klasikal dan tatap muka menjadi metode online mendapatkan berbagai reaksi dari mahasiswa (Kusnayat et al., 2020).

Dinamika kebijakan pembelajaran daring di era pandemi Covid-19 saat ini untuk menuntut kreativitas serta keterampilan dosen atau guru dalam menggunakan teknologi melalui jaringan telekomunikasi. Peserta didik, siswa atau mahasiswa diharapkan mampu mengakses jaringan aplikasi yang digunakan dalam pembelajaran daring seperti, Zoom, Google Meet, Google Clascroom, Ruangguru dan beberapa aplikasi lainnya (Saputra: 2020). Menurut Jagad dan \& Nurgiansah (2021) media pembelajaran yang menarik dan menyenangkan mampu menghilangkan rasa bosan dalam pembelajaran daring. Untuk perkuliahan daring mahasiswa memerlukan variasi tersendiri untuk menghilangkan kejenuhan. Selain penggunaan media pembelajaran daring yang menarik, dalam perkuliahan online, kreativitas dosen sangat diperlukan dalam pembelajaran daring guna menghindari rasa bosan (Hikmat et al., 2020).

Menurut Arizona et al (2020). kendalakendala yang paling sering muncul selama pelaksanaan pembelajaran daring (Online) yaitu paket internet yang tidak dimiliki oleh perseta didik, siswa atau mahasiswa. Menurut (Ahmad \& Ambotang, 2020) terkait pelaksanaan pembelajaran jarak jauh pada masa penyebaran pandemi Covid-19 menimbulkan berbagai persoalan. Salah satu contoh persoalan tersebut, diantaranya baik dosen atau guru maupun perserta didik dan mahasiswa masih kesulitan dalam mengoprasikan aplikasi daring tersebut. Ada beberapa kendala yang terjadi secara tidak merata di seluruh wilayah, Misalnya di Kota Surabaya salah satu termasuk kota besar di Kota Jawa Timur dengan adanya dukungan pembangunan dan teknologi yang maju masih dirasakan kurangnya maksimal, dalam hal dinamika kebijakan pembelajaran daring selama pandemi Covid-19 saat ini disebabkan faktor jaringan/internet yang timbul tenggelam atau hilangnya sinyal dari tangkapan leptop, handphone guru dan siswa. Dengan demikian, Akibat pembelajaran daring di plosok-plosok wilayah masih minimnya akses jaringan internet/sinyal akan jauh lebih berat dilaksanakan untuk mengikuti pembelajaran daring. Pembelajaran daring (Oline) merupakan salah satu solusi untuk ditetapkan dan melaksanakan kegiatan belajar mengajar. (Rachmat \& Krisnadi: 2020). Kajian ini berkaitan dengan era pandemi Covid-19 terhadap dinamika kebijakan pembelajaran daring dalam dunia pendidikan diseluruh Indonesia, kajian tersebut yang menarik diulas sebagai bentuk pembacaan ilmiah terhadap fenomena pembelajaran daring di era pandemi Covid19 saat ini. Dari berbagai pembelajaran daring selama pandemi Covid-19 di seluruh Indonesia tersebut dapat menjadikan sebagai data penelitian pustaka (Library Research), sehingga menjadikan perhatian di dunia praktisi pendidikan, guru, maupun dosen yang mengkaji fenomena ini sebagai peluang menggagas paradigma baru pembelajaran daring dimasa depan.

\section{METODOLOGI}

Metode peneltian, dalam artikel ini yaitu menggunakan metode penelitian deskriptif kualitatif. Penelitian kualitatif berfokus pada latar secara alamiah dengan maksud menerjemahkan fenomena yang terjadi melalui metode yang ada (Moleong, 2014). Metode tersebut bertujuan untuk memahami realitas dan makna dari peristiwa yang diketahui melalui hasil penelitian jurnal terdahulu juga memperkuat data yang dituliskan oleh peneliti dalam penelitian ini. Sumber data yang di peroleh dari studi pustaka yang menggunakan Studi Literatur seperti; Jurnal, proseding, artikel, majalah, buku, laporan kegiatan, media berita, sumber tertulis lainnya regulasi kebijakan 
terkait pembelajaran daring di Era Pandemi Covid-19.

Metode dan teknik pengumpulan data yang digunakan meliputi kepustakaan; pengamatan (observasi), wawancara (interview). Sesuai dengan sumber data seperti yang dijelaskan di atas, maka dalam penelitian ini pengumpulan data dengan cara; studi kepustakaan, terhadap data sekunder dikumpulkan dengan melakukan studi kepustakaan, yaitu; dengan mencari dan mengumpulkan serta mengkaji peraturan perundang-undangan, hasil penelitian, jurnal ilmiah, artikel ilmiah, dan makalah seminar yang berhubungan kebijakan pembelajaran daring.

Interview (wawancara) dilakukan dengan teknik wawancara tidak terarah (nondirective interview) atau tidak terstruktur (free flowing interview) yaitu dengan mengadakan komunikasi secara langsung kepada informan, dengan menggunakan pedoman wawancara. Obervasi yaitu mengadakan penelitian, terjun secara langsung pada objek yang menjadikan sasaran untuk diperoleh sumber-sumber data yang valid.

\section{HASIL DAN PEMBAHASAN}

Kebijakan pemerintah melalui kementrian pendidikan dan kebudayaan telah mengeluarkan kebijakan tentang Pelaksanaan Pendidikan Dalam Masa Darurat Coronavirus Disease (Covid-19). Berdasarkan Surat Edaran Mendikbud Nomor 4 Tahun 2020 tentang Pelaksanaan kebijakan pendidikan dalam masa darurat penyebaran Covid-19. (Nur, A dan Chusnul, C :2021). Menurut (Gebi Sajow : 2021) berdasarkan hasil wawancara dengan informan, pelaksanaan kebijakan sangat mempengaruhi berhasil atau tidaknya suatu kebijakan yang dibuat oleh pemerintah, namun dari kebijakan yang dikeluarkan tentunya tidak dapat memastikan semuanya akan berjalan secara efektif dan efesien. Dinamika pembelajaran jarak jauh memang tidak seefektif belajar tatap muka. Dalam pelaksanaan pendidikan melalui pembelajaran daring memiliki tantangan khusus tidak terlepas dari jaringan internet. Koneksi internet menjadi salah satu kendala yang dihadapi perserta didik, dosen, guru, siswa dan mahasiswa, jaringan internet yang benar-benar belum merata dan tidak semua lembaga pendidikan dapat menikmati jaringan internet. Jika ada jaringan internet kondisinya masih belum mampu mengkaver semua media daring. Dimana tempat lokasi peserta didik, dosen, guru, siswa dan mahasiswa yang terpisah saat melaksanakan pembelajaran daring , pendidik, dosen atau guru tidak dapat mengawasi secara langsung dalam kegiatan siswa atau mahasiswa selama proses pembelajaran daring, tidak jarang banyak murid yang merasa jenu atau bosan, ketidaksiapan teknologi sehingga membuat pembelajaran daring dalam jaringan tidaklah seefektif yang diharapkan (Gebi Sajow : 2021).

Dinamika pelaksanaan proses pendidikan yang efisien yaitu memperdayagunaan sumber daya seperti; tenaga, waktu dan biaya tepat sasaran dengan kelulusan dan produktifitas pendidikan yang optimal. Dinamika pembelajaran daring membutuhkan tempat fasilitas sebagai penunjang kegiatan pembelajar daring. Pelaksanaan dalam penunjang proses pendidikan melalui jaringan internet tentu saja bukan merupakan pekerjaan yang tanpa halangan. Salah satunya yang dilakukan oleh pemerintah dengan adanya Surat Edaran Nomor 4 Tahun 2020. Penyebab kendala lainnya adalah kurangnya tempat fasilitas penunjang pelaksanaan pembelajaran jaringan internet atau Wifi, ketersedian kouta yang dibutuhkan biaya yang cukup mahal harganya, bagi peserta didik, mahasiswa dan siswa, guru, dosen gunanya untuk memfasilitasi kebutuhan pembelajaran daring melalui jaringan internet/wifi. Perubahan pembelajaran tatap muka menjadi pembelajaran daring (Oline), tidak semudah dilakukan oleh peserta didik, guru, siswa, mahasiswa dan dosen. Sehingga usaha yang harus ditetapkan dan dilakukan semaksimal mungkin oleh pihak-pihak sekolahan maupun universitas untuk memberikan pelayanan yang terbaik dalam pembelajaran daring (Oline) bagi peserta didik, siswa dan mahasiswa dalam melaksanakan pembelajaran daring melalui jaringan internet/wifi.

Dari hasil penelitian (Sajow, 2021) masing-masing sekolahan memiliki caracara tersendiri dalam meningkatkan sistem 
pembelajaran daring, ada yang menyediakan pelayanan wifi, ada yang diberikan kouta internet secara gratis. Untuk meningkatkan dan kesuksesan pembelajaran daring ini tergantung pada kedisiplinan semua perserta didik dan semua pihak yang terkait. Kebijakan pembelajaran daring ini, bisa menjadikan sebuah pengalaman baru bagi peserta didik, mahasiswa, siswa, guru maupun dosen. Pelaksanaan pembelajaran daring ini membutukan kerja keras, tempat dan fasilitas serta bantuan untuk menujang kegiatan pembelajaran daring melalui jaringan inaternet. Pendidikan diharapkan untuk meningkatkan mutu kehidupan dan dapat menghasilkan perserta didik yang bermutu, berkualitas, berpengetahuan, keterampilan dan bertanggung jawab.

Kondisi pembelajaran daring saat ini belum dapat disebut ideal karena masih terdapat berbagai hambatan dan kendala yang dihadapi saat ini. Hambatan tersebut menjadi tantangan dalam melakukan pembelajaran daring melalui internet/wifi, agar terselenggaranya di tengah-tengah pandemi Covid-19 yang terjadi saat ini. Kendala atau hambatan yang di hadapi saat ini pada saat pelaksanaan pembelajaran daring antara lain yang berkaitan dengan kesiapan sumberdaya manusia, belum adanya kurikulum yang tepat maupun keterbatasan sarana prasarana, khususnya dukungan teknologi informasi dan jaringan internet, wifi, serta kurang jelasnya arahan pemerintah daerah setempat. Ketersiapan dukungan sumberdaya manusia meliputi; Pendidik, dosen, guru, dan peserta didik, dukungan orang tua merupakan bagian terpenting dalam melakukan pembelajaran daring (Arifa, 2020).

Pada saat pandemi Covid-19 ini, banyak memberikan dampak besar pada berbagai bidang, salah satunya dibidang dunia pendidikan. Dampak tersebut, salah satunya banyak keluhan-keluhan, baik dari pendidik, peserta didik, maupun orang tua siswa terkait pelaksanaan pembelajaran daring dari rumah. Tenaga pendidik banyak mengeluhkan keterbatasan dan ketersediaan prasarana teknologi, informasi, kemapuan untuk pengoperasian dan keterbatasan jaringan internet, wifi/ Sinyal di beberapa daerah (Arifa, 2020). Pelaksanaan pembelajaran daring aplikasi yang paling banyak digunakan selama pembelajaran daring disaat pandemi Covid19 adalah aplikasi yang efektif dan bisa dilakukan pada saat pembelajaran 2 arah secara langsung seperti, Google Classroom atau Zoom.

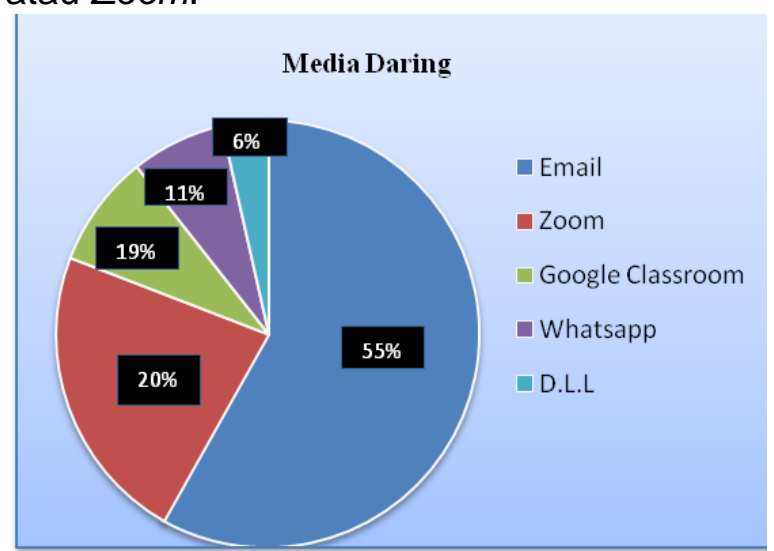

Gambar 1. Media yang Digunakan Dalam Pembelajaran Daring

Berdasarkan Gambar 1 tersebut, media daring yang sering dipergunakan pembelajaran adalah aplikasi email yang berada berurutan pertama berjumlah $55 \%$, pada hal email ini tidak bisa dipergunakan untuk pembelajaran face to face. Email ini berbeda dengan Zoom yang lebih efektif dipergunakan untuk pembelajaran daring secara langsung seperti; rapat, perkuliahan, workshop maupun kegiatan lainnya. Aplikasi Zoom ini berurutan ke dua berjumlah $20 \%$. Aplikasi Zoom ini dikenal dan dipergunakan sejak pandemi Covid-19 sampai saat ini. Aplikasi Google Classroom berurutan ke tiga berjumlah $19 \%$. Sisanya $11 \%$ aplikasi yang dipergunakan seperti; Google Meet, Ruang Guru, Group Whatssap, Google for Education, Rumah Belajar, Microsoft Office 365, Website E-Learning, Live Chat dan lain lain.

Kelemahan pembelajaran daring menunjukkan bahwa $38 \%$ responden merasa jenuh/bosan, karena pemahaman terhadap materi kurang. Selanjutnya $29 \%$ responden mengeluhkan tidak adanya sinyal, keterbatasan akses internet, serta biaya akomodasi kuota internet yang terbilang mahal harganya. Borosnya kuota disebabkan bahwa aplikasi atau semua konten yang tampil berbentuk video dan sudah disetting default dengan resolusi yang sangat tinggi.

Dinamika kebijakan publik yang membuat dan mengatur pendidikan yang sudah 
sepantasnya menjadikan kewajiban oleh pemerintah, oleh sebab itu pemerintah harus mewujudkan kebijakan pendidikan sesuai dengan yang diamanatkan oleh undangundang. Bahwa kebijakan pendidikan adalah kebijakan publik, berkenaan dengan kumpulan hukum atau aturan yang mengantur pelaksanaan sistem pendidikan, tercakup didalam tujuan pendidikan dan mencapai tujuan tersebut (Nugroho, 2008). Kebijakan pembelajaran daring ini sebenarnya bisa dilakukan degan baik berdasarkan sarana prasarana terpenuhi.

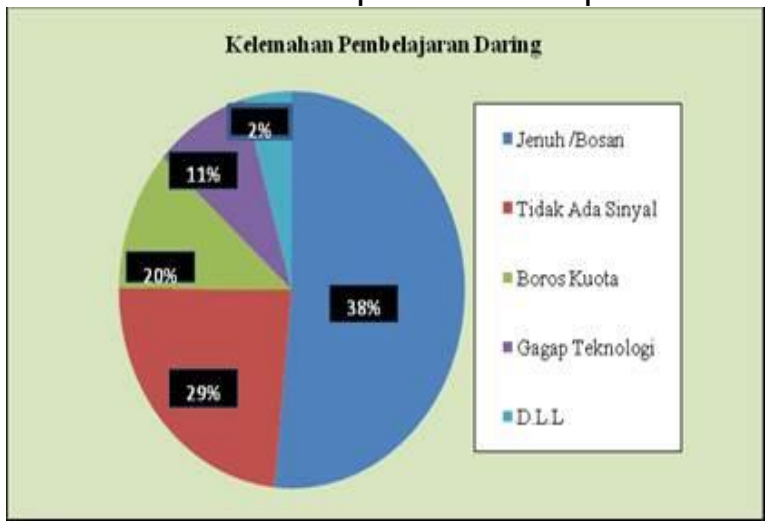

Gambar 2. Kelemahan Pembelajaran Daring

Berdasarkan Surat Edaran Nomor 3 tahun 2020 pada satuan pendidikan dalam nomor 36962/MPK.A/HK/2020 tentang pelaksanaan pendidikan dalam masa darurat Coronavirus Disease (Covid-19), pelaksanaan kegiatan pembelajaran dilakukan secara daring melalui jaringan internet/ kuota. Terkait dalam proses pelaksanaan yang diterapkan kepada masyarakat supaya dapat menyelesaikan semua pekerjaan dirumah. Pendidikan di Indonesia juga menjadi salah satu bidang yang terdampak akibat pandemi Covid-19 pada saat ini. Dalam penggunaan sistem pembelajaran daring ini, terkadang timbul permasalahaan yang di hadapi oleh peserta didik, siswa, mahasiswa dan guru serta dosen, Contoh seperti memberikan materi pelajaran yang belum diselesaikan dan di sampaikan oleh para guru atau dosen kemudian, guru mengganti dengan tugastugas lainnya. Hal ini menjadi permasalahan dan keluhan bagi siswa/ mahasiswa karena penyebab tugas yang diberikan oleh guru atau dosen lebih banyak (Siahaan, 2020).

Tabel 1. Penghambat Berkomunikasi dalam Pembelajaran Daring

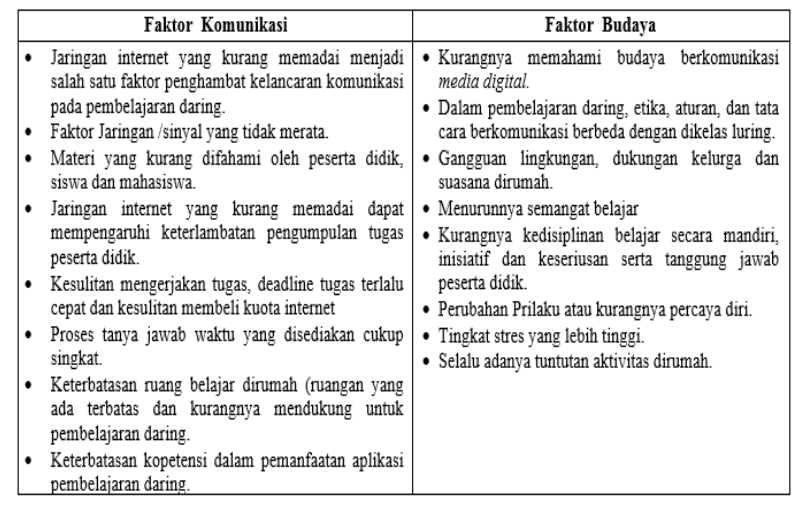

Tabel 2. Hambatan Komunikasi (Personal)

\begin{tabular}{|c|c|}
\hline No. & Hambatan Komunikasi (Personal) \\
\hline 1 & 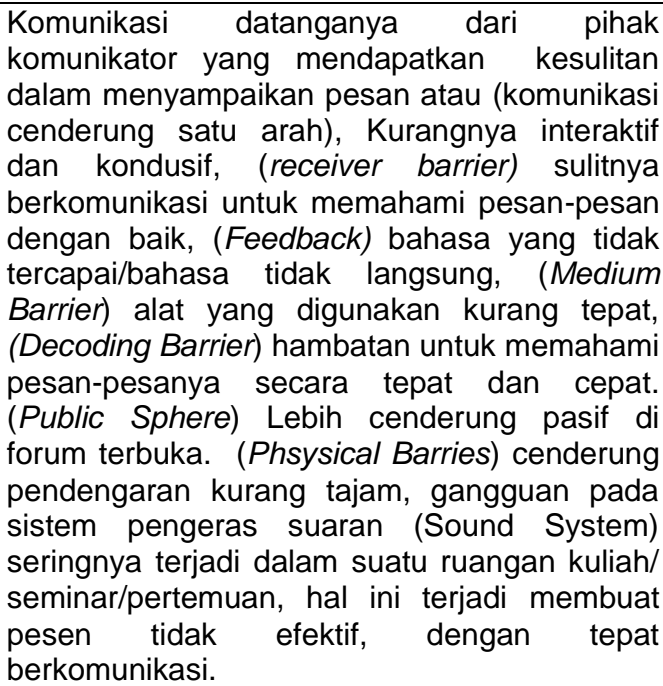 \\
\hline 2 & $\begin{array}{l}\text { kasi (Sychossial Noies) yaitu hambatan } \\
\text { tan dalam aspek kebudayaan, } \\
\text { aan bahasa, adat istiadat, presepsi dan } \\
\text { ai yang di anut, hal ini lebih cederung } \\
\text { kedua belah pihak yang berkomunikasi } \\
\text { tbeda pula. }\end{array}$ \\
\hline 3 & $\begin{array}{l}\text { Proses komunikasi berdiskusi kurang berjalan } \\
\text { dengan baik, Tidak semua peserta didik, } \\
\text { siswa, mahasiswa, dapat memiliki kemampuan } \\
\text { berkomunikasi dan mampu memahami materi } \\
\text { pembelajaran daring (Oline) sehingga harapan } \\
\text { pembelajaran daring tidak sepenuhnya } \\
\text { tercapai. }\end{array}$ \\
\hline 4 & $\begin{array}{l}\text { Komunikasi dari pengiriman pesen yaitu; } \\
\text { komunikasi lewat pesan yang akan di } \\
\text { sampaikan belum jelas bagi dirinya atau } \\
\text { pengiriman pesan, Hal ini dipengaruhi oleh } \\
\text { perasaan atau situai emosional sehingga } \\
\text { mempengaruhi motivasi seperti, mendorong } \\
\text { seseorang dalam bertidak sesuai dengan } \\
\text { keinginan serta kebutuhan dan kepetingan } \\
\text { seseorang. (Syahrul Abidin :2020) }\end{array}$ \\
\hline
\end{tabular}

\section{KESIMPULAN}

Berdasarkan hasil penelitian dan pembahasan di atas, tersebut bahwa dinamika kebijakan pembelajaran daring di 
era pandemi Covid-19 ini dapat dilakukan dengan baik. Pandemi Covid-19 begitu besar dampaknya bagi pendidikan. Untuk memutus mata rantai penyebaran pandemi Covid-19 saat ini pembelajaran secara luring melalui tatap muka, sekarang menjadi metode pembelajaran secara melalui berbagai aplikasi seperti; Zoom, Google Classroom, Ruang Guru, Google Meet, Whatssap, E-Learning, serta melalui group Whatssap. Kegiatan pembelajaran daring berjalan dengan baik, sesuai kreatifitas pendidik (dosen dan guru) dalam memberikan bahan-bahan materi, soal-soal latihan kepada peserta didik. Pembelajaran daring membutuhkan sumberdaya yang memadai, terutama sumberdaya digital dan akses teknologi (Internet). Jaringan internet yang tidak merata atau internet yang kurang memadai menjadi salah satu faktor penghambat kelancaran komunikasi pada pembelajaran daring. Terkait aspek finansial peserta didik dalam ketersedian akses kuota (internet) turut menjadi penghambat proses pembelajaran daring.

\section{DAFTAR PUSTAKA}

Abd. Rahim Mansyur. 2020. Dampak COVID-19 Terhadap Dinamika Pembelajaran Di Indonesia. Education and Learning Journal. Vol. 1, No. 2, Juli 2020, pp. 113-123.

Ahmad, A \& Ambotang A. 2020. Pengaruh Kecerdasan Emosi, Kecerdasan Spiritual dan Persekitaran Keluarga terhadap Stres Akademik Murid Sekolah Menengah,. Malaysian Journal of Social Sciences and Humanities (MJSSH). Vol. 5 (5):12-23.

Aji, R. H. S. 2020. Dampak COVID-19 pada pendidikan di Indonesia: Sekolah, keterampilan, dan proses pembelajaran. Jurnal SALA: Jurnal Sosial \& Budaya Syari. Vol. 7 (5), 395-402.

Aprilliani Puspitasari. 2021. Dampak Covid19 Terhadap Sektor Pendidikan di Indonesia. Artikel. Kamis, 01 Juli 2021. 14:30 WIB
Arizona, K., Abidin, Z., \& Rumansyah, R. 2020. Pembelajaran Online Berbasis Proyek Salah Satu Solusi Kegiatan Belajar Mengajar Di Tengah Pandemi Covid-19. Jurnal Ilmiah Profesi Pendidikan, Vol. 5 (1), 64-70.

Fieka Nurul Arifa. 2020. Tantangan Pelaksanaan Kebijakan Belajar Dari Rumah

Dalam Masa Darurat Covid-19. Info Singkat. Kajian Singkat Terhadap Isu Aktual Dan Strategis. Vol. XII, No. 7///Puslit/April/2020.

Gebi Sajow. 2021. Kebijakan Pemerintah Dalam Pelaksanaan Pendidikan Menengah Melalui Pembelajaran Dalam Jaringan (Daring). Jurnal Politico. Vol. 10, No 4 -2021.

Hikmat, Hermawan, E., Aldim, \& Irwandi. 2020. Efektivitas Pembalajaran Daring Selama Masa Pandemi Covid-19: Sebuah Survey Online. Digital Library, UIN Sunan Gung Djati, Bandung, 1-7.

Jagad, A, D, \& T Heru, N. 2021. Efektivitas Pembelajaran Daring di Masa Pandemi COVID 19 Bagi Mahasiswa, Universitas PGRI Yogyakarta. Jurnal Basicedu. Volume 5 Nomor 1 Halaman 367-375.

Kusnayat, A., Muiz, M.H., Sumarni, N., Mansyur, A.S., \& Zaqiah, Q.Y. 2020. Pengaruh teknologi pembelajaran kuliah online di era Covid-19 dan dampaknya terhadap mental mahasiswa. Jurnal Edukasi dan Teknologi Pembelajaran, Vol. 1 (2), 153-165.

Moleong, Lexy. J. 2014. Metode Penelitian Kualitatif, Edisi Revisi. PT Remaja Rosdakarya, Bandung.

Matdio Siahaan. 2020. Dampak Pandemi Covid-19 Terhadap Dunia Pendidikan. Jurnal Kajian IImiah (JKI). Edisi Khusus No. 1 (Juli 2020),

Nur, A, \& Chusnul, C. 2021. Dinamika Pembelajaran Daring Melalui Belajar Dari Rumah (Bdr) Pada Paud Miftahul Ulum Saat Pandemi Covid 19. DAR EL-ILMI: 
Jurnal Studi Keagamaan, Pendidikan dan Humaniora.

Rachmat, A., \& Krisnadi, I. 2020. Analisis Efektifitas Pembelajaran Daring (Online) Untuk Siswa SMK Negeri 8 Kota Tangerang Pada Saat Pandemi Covid 19. Magister Teknik Elektro Universitas Mercu Buana, 1-7.

Riant, Nugroho. 2008. Kebijakan Publik Formulasi, Implementasi, dan Evaluasi. Jakarta: PT. Elex Media Komputindo kelompok gramedia.

$\begin{array}{lrr}\text { Soraya Fadhal: } & 2020 . & \text { Hambatan } \\ \text { Komunikasi dan } & \text { Budaya } & \text { dalam } \\ \text { Pembelajaran } & \text { Daring pada Masa } \\ \text { Pandemi } & & \text { COVID-19. }\end{array}$
https://eprints.uai.ac.id/1539/1/ILS000121 Isi-Artikel.pdf

Sandra G, C. \& Dedi, R, R. 2020. Komunikasi Digital Pada Pembelajaran Secara Daring Dimasa Pandemi Covid19. Jurnal Bonanza: Manajemen dan Bisnis. Vol.1 (2) November 2020 Halaman; 56-65.

Wahyu Aji Fatma Dewi. 2020. Dampak Covid-19 Terhadap Implementasi Pembelajaran Daring Di Sekolah Dasar. Edukatif : Jurnal IImu Pendidikan. Volume 2 Nomor 1 April 2020 Halm 55-6 